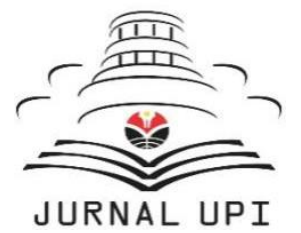

THE JOURNAL GASTRONOMY TOURISM

Volume 8 Issue 1, June 2021, 21-31

Tersedia daring di:

https://ejournal.upi.edu/index.php/gastur

Gastronomy Tourism Journal

\title{
Feasibility Study And Business Planning Of Rumahmakan.Online Digital Menu Whatsapp Ordering System
}

\author{
Fanji Lesmana, Dewi Turgarini \\ Indonesia University of Education, Dr. Setiabudhi street, No. 229, Bandung 40154, Indonesia \\ *Corresponding Author. E-mail: fanjilesmana@upi.edu (Fanji Lesmana)
}

\begin{abstract}
Food delivery service business have increased rapidly in the era of the Covid-19 pandemic. People use new business model devices in their daily lives. E-commerce/platform of food delivery service is an integrated business system that started from the food provider to the food buyers. Commonly, the food delivery service platform set the "Cost of Technology" which is added to the calculation of Cost of Good Sold (CoGs/HPP). The cost of service burden the food provider. Therefore, rumahmakan.online provides solution for food/restaurant providers, who have a personal digital menu. Food buyers can make orders via WhatsApp to the food provider/restaurant's WhatsApp number by using these platforms.
\end{abstract}

Keywords: Online order; Restaurant; Digital menu; Bisnis plan; WhatsApp order.

First Received:
February 2021

Final Proof Received:

May 2021
Revised:

March 2021
Accepted:

April 2021
Published:

June 2021 


\section{Introduction}

The COVID-19 pandemic that occurred in Indonesia hit various business sectors. Preventing the spread of the Covid-19 virus forced the government to limit the community's movement to affect Indonesia's economy. It has also had a fairly severe impact on the tourism industry. Based on a survey conducted by the ministry of tourism and the creative economy nationally, the COVID-19 pandemic has resulted in $92 \%$ of the 5,242 tourism sector workers losing their jobs. The business most affected is an accommodation of $87.3 \%$, transportation $9.4 \%$ restaurant by $2.4 \%$ and $0.97 \%$ are other businesses (Suprihatin, 2020).

The restaurant industry's ability to survive and mitigate the impact of the COVID-19 pandemic is due to the industry's rapid adoption of technological advances. One of the most recent technological advances is the widespread use of the internet in all aspects of life, particularly business, which has boosted the economy (C. Ningsih, YJ Choi, 2018). Kompas.com reported that Gofood had increased its partner count to 750,000 . The number of merchants on Grab Food increased by 153\%. According to Detik.com, GrabFood's gross transaction value reached Rp. 83 trillion, while GoFood's was Rp. 28 trillion. This record is also supported by data from the Demographic Institute of the Faculty of Economics and Business, the University of Indonesia, which shows that spent 97 percent of digital consumer expenditures per month during the COVID-19 pandemic on food orders, 76 percent on delivery services, and 75 percent on transportation.

This e-commerce food platform/online food purchase service provider requires a fee cut for merchant partners (culinary businessmen). Grab food itself in 2021 has a $30 \%$ discount scheme by promising an increase in purchase volume of 100 times the previous purchase volume. Become a merchant at Grab food. Meanwhile, Gofood has a $20 \%$ discount scheme + IDR5000 - for partners registered after March 5th, 2021, and partners who joined before that date are subject to a discount of $12 \%$ + IDR 5000 or are allowed to change to a $20 \%+$ scheme. Rp.1000,--

The fee requirement in the form of a cost of technology charged to the merchant is sufficient to influence the determination of the cost of goods sold (CoGs), and the merchant begins to apply different prices on each online and offline platform; it is not uncommon for merchants to reduce profits obtained from offline sales to compete on the food e-commerce platform. Furthermore, consumer perceptions of merchants are harmed by the disparity between offline and online prices. In this predicament, an online restaurant was founded to provide solutions in technology cost reduction, sales optimization, and branding via digital marketing. In addition, an online restaurant can help implement the health protocol applied in physical restaurants because it can minimize contact.

To find out either an online restaurant is feasible or not, a feasibility study is carried out. The aspects discussed are market aspects, management aspects, technical aspects, and financial aspects.

\section{Studi Literatur}

\subsection{Digital Marketing}

According to Ryan (Hanafiah \& Prasetya, 2021), digital marketing is a marketing method carried out with the help of digital instruments, particularly the internet and the various applications contained in it, as well as equipment that supports the use of these media, which allows the creation of a network or connection with many parties, in this case between the producer/seller and the customer, without the use of intermediaries. Meanwhile, (Chaffey and 
Ellis, 2016) define digital marketing as using digital technology platforms in conjunction with traditional media to achieve marketing objectives.

\subsection{Customer Relationship Management}

Customer Relationship Management (CRM) is an approach to managing corporate relationships with customers. This relationship is expected to increase customer loyalty to the company (Syabania \& Rosmawarni, 2021). Meanwhile, according to (Rosanti \& Darma Tuah Putra, n.d.)Customer Relationship Management (CRM) is a business strategy that aims to build and maintain relationships between companies and their customers. CRM is a term used in the IT industry to describe methodologies, systems, software, and/or other web-based applications that can assist an enterprise (enterprise) in managing its customer relationships.

Utami (Carissa \& Onna, 2014) explain the process of Customer Relationship Management (CRM) is collecting customer data, analyzing customer data and the identity of target customers, developing CRM programs, and implementing CRM programs. Customer Relationship Management (CRM) allows companies to provide services to customers directly and optimally by developing relationships with each valuable customer through customer information or databases (databases) owned by the company. In this case, the company employs a Customer Relationship Management (CRM) strategy intending to remain focused on customers through customer information or databases.

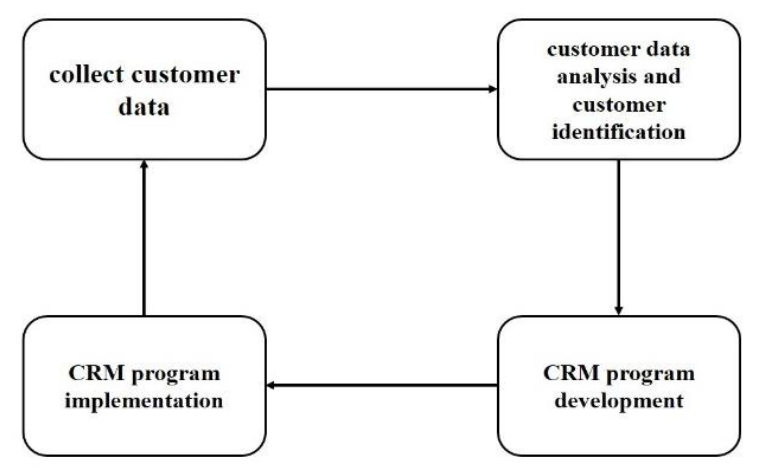

Figure 1. CRM process

Source: researcher data, 2021

\subsection{Co-Branding}

Co-branding is the use of two brands for one product, also known as branding collaboration, and this strategy is used to capitalize on the strengths of both of these brands (Pranawukir \& Sukma, 2021). Through the exchange of technological knowledge, co-branding can bring new customers to a product, refresh the brand image, increase market share, or develop company technology.

Co-branding is also a method to minimize costs. Co-branding is a brand alliance strategy where two or more brands are simultaneously presented to consumers. There are various co-branding activities in the market, ranging from advertising several brands in one ad to the combined brand products of the two companies. Can Strengthen the image of a brand by borrowing the higher performance of its partner brand. (Sarinastiti \& Vardhani, 2019). 
Co-branding is a brand alliance strategy where two or more brands are simultaneously presented to consumers. There are various co-branding activities in the market, ranging from advertising several brands in one advertisement to the combined brand products of the two companies. Can strengthen the image of a brand by borrowing the higher performance of a partner's brand. The co-branding position matrix, which includes various types of positions between two companies, creates a choice in four general parts to place the merged brand, which provides for Coalition, Coordination, Collaboration, and Cooperation. All four are also influenced by two dimensions which include co-branding type and co-branding level. Co-branding refers to operational forms associated with co-branding situations, such as mergers (company A merges with company B) and joint ventures (A and B invest collectively). In contrast, the co-branding level is related to the co-branding process that occurs only in a department (Department A corresponds to Department B) or related to the whole company (Company A corresponds to Company B) (Chang, 2009).

\subsection{Segmenting, Positioning dan Targeting}

\subsubsection{Segmenting}

According to Morissan (2010), Eric Berkowitz and colleagues define market segmentation as dividing a market into distinct groups with similar needs and responses to marketing actions. Morissan (2010) suggests the basics of segmenting the market, which consists of:
a. Demographic Segmentation
b. Geographic Segmentation
c. Geodemographic segmentation
d. Psicographic Segmentation
OC Ferrell and Michael D Hartline, in their book "Marketing Strategy," suggest that the criteria for effective market segmentation are (Ferrel \& Hartline, 2011):

a. Measurable: The size, purchasing power, and characteristics of the segment can be measured.

b. Substantial: A segment that is large enough and profitable to serve. A part should be a largely homogeneous group that deserves to be pursued with a customized marketing program.

c. D Accessibility: Segments can be reached and can be served effectively.

d. Differentiable means that the segment is conceptually distinct and responds differently to different elements and marketing mixes.

e. Actionable: Effective programs can be formulated to attract and serve segments.

\subsubsection{Targeting}

According to Philip Kotler, Targeting is "the process of evaluating the attractiveness of each market segment and selecting one or more segments to enter." Thus, it refers to the process of assessing the attractiveness of each market segment and choosing one or more to enter. In this targeting process, the company must choose a market segment that suits its product. The problem of this target is how to choose, select, and be able to reach the market. Because the target of a product is the targeted market according to marketing activities (Kotler et al., 2017) that, there are several types of target market strategies, including:

a. Undifferentiated marketing or mass marketing

Using this strategy, the company decides to ignore the different market segments and fill the entire market with a single offer. That is, the plan must focus more on specific consumer needs than others.

b. Differentiated marketing

In this strategy, the company targets several market segments and designs separate offerings for each market segment. For example, by offering a 
wide variety of products and marketing into parts, the company hopes to get higher sales and has a strong position in each part.

c. Concentrated marketing

The emphasis in this strategy is on marketing products to one or more segments/groups of specific buyers so that product marketing is limited to groups of buyers with high potential. The company tries to provide the best product for its market share by focusing on a specific segment. In terms of production, distribution, and promotion, the company will be more cost-effective because everyone concentrates solely on one or two groups.

d. Micromarketing

The company will produce customized products for specific individuals (individual marketing) and specific locations under this strategy (local marketing).

\subsubsection{Positioning}

Kotler (2006: 265) explains several ways of product positioning that marketers can do in marketing products to consumers. This positioning measures which area our product or brand is in (Durianto et al., 2004). Is following the target we want. For that, the following steps are needed:

a. Identify several distinct sets of competitive advantages. This set is used to build a position.

b. Choosing the proper competitive advantage.

c. Choose the overall positioning strategy.

\subsection{Promotion Mix}

Buchari Alma (2016: 205) defines the marketing mix as a strategy for interfering in marketing activities to find the best combination that produces satisfactory results. According to Kotler and Armstrong (2016: 47), the marketing mix consists of four (4) significant elements controlled by the company: product, price, place, and promotion. Thus, the marketing mix itself is a tool that can be owned and used by the players to influence consumer responses in the target market, which includes the product, price, location, and promotion.

a. Product

Saladin (2016: 71), a product is anything that can offer to the market to get attention, buy, use, or consume, and that can satisfy wants and needs. According to Kotler and Keller (2016: 47), a product is anything that can offer to a market to satisfy wants and needs.

b. Place

Tjiptono (2016: 185) defines distribution channels as marketing activities that seek to expedite and facilitate the delivery of goods and services from producers to consumers so that their use follows what is needed (type, quantity, price, place, and when required).

c. Price

Kotler and Armstrong (2015: 312), price is the amount of money charged for a product or service, the sum of the values that customers exchange for the benefit of having or using the product or service. Tjiptono (2016: 218) states that price is the only element of the marketing mix that brings income or income to the company. Meanwhile, according to Buchari Alma (2016:169), price is the value of an item expressed in money. According to (Rangkuti, 2010) Perceived price is the relative cost that consumers must spend to obtain the desired product or service. According to (Peter Paul, 2010), Price perception is related to how well price information is understood and interpreted by consumers. Therefore, when consumers evaluate and research the price of a product, their behavior has a strong influence.

According to Victor et al. (2019), pricing strategy is critical to achieving long-term 
revenue management in any business. Moreover, in a competitive environment, price management is an essential marketing and effective revenue management component. Therefore, it has piqued the interest of both researchers and practitioners. (Guo \& Zheng, 2017).

\section{d. Promotion}

Kotler and Keller (2016: 47), promotion is an activity that communicates product advantages and persuades target customers to buy it. The above definition can conclude that promotion influences and persuades target customers to purchase or divert purchases of products produced by the company. Therefore, promotion can be defined as a form of marketing communication. Marketing communication is a marketing activity that seeks to disseminate information, influence, persuade, and remind the target market of the company and its products to be willing to accept, buy, and be loyal to the products offered by the company concerned.

\section{Method}

This qualitative study uses descriptive analytical methodologies using library research and secondary data to describe a feasibility study for developing an rumahmakan.online business.

\subsection{First Stage}

What is done in this study is to make initial observations. This initial observation was carried out to see and identify market availability by looking at the movement of secondary data for restaurants registered as merchants on the food e-commerce platform. Following receipt of an initial description, discovered several issues, including the emergence of disparities in the cost of goods sold as a result of fees charged by the business aggregator, in this case, the food e-commerce platform; additionally, because of the large number of merchant listings on one food e-commerce platform, only merchants are listed. As a result, specific merchants have top listings, while others are difficult to find in the listings. Therefore, this research aims to identify and find solutions for optimizing digital marketing in the 4.0 industrialization era.

\subsection{Second Stage}

After the market aspect, collected data for the technical part, as for other data, website users, application users, social media users, payment gateway selection data (payment methods). This is used to find out what will use technology in the development of the rumahmakan.online platform and find out which technology is more comfortable for consumers to use. After that, segmenting, targeting, and positioning are determined based on the swot analysis of rumahmakan.online. This is intended for one of the factors of the pricing strategy.

\subsection{Thrid Stage}

The last aspect being discussed is the financial aspect and social benefits. This aspect is also inseparable from the previous aspects. Total business costs are calculated in this financial aspect, including virtual office costs, operational equipment, labor, servers, CDN (content delivery network), promotions, and marketing. In addition to determining the selling price, consider the cost of free services with feature limitations subsidized from paid service price. Based on the data discussed, a literature study was also conducted on whether the services provided by the rumahmakan.online are feasible to establish.

\section{Result and Discussion}

Based on preliminary observations, it is known that 750,000 merchants have joined Gofood. This year has increased by $50 \%$ based on data from indotelko.com (2021, January 23rd). Meanwhile, on the grabforgood.id page, Grabfood recorded an 
increase of approximately 78000 merchants joining the GoFood service. On the other hand, GrabFood reaches Eighty-three trillion rupias while GoFood reaches Rp. 28 trillion. This record is also supported by the databox of the Demographic Institute of the Faculty of Economics and Business, the University of Indonesia, which states that it spent 97 percent on food orders, 76 percent on delivery services, and 75 percent on transportation during the COVID-19 epidemic. From the data above, it can be seen that during the COVID-19 pandemic, there was an increase in users/purchases of food online.

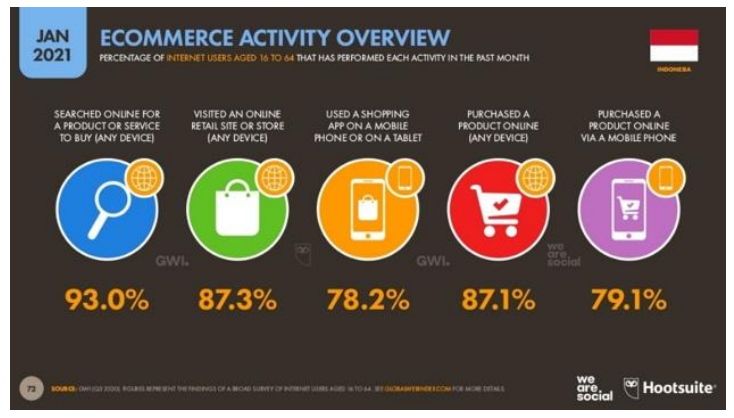

Figure 2. Ecommerce Activity overview Source: we are social Hootsuite, 2021

Based on the data presented by We Are Social shows that $93.0 \%$ of Indonesians like to do a preliminary search on the goods to be purchased, as many as $87.3 \%$ of people visit e-commerce websites through various devices, and as many as $87.1 \%$ make purchases. On any device and $79.1 \%$ make purchases through their smartphone applications. Seeing this, the use of the web platform is better than applications because it is more widely used and can optimize the digital marketing strategy that will implement.

Because of the growth in demand or online sales transactions, culinary businesses take the easy way out by joining a food e-commerce platform without contemplating the long-term consequences.
The rise in sales, along with a co-branding approach, ensured that everything went well. However, because each food ecommerce platform has a different charge system, including online and offline price variances, this co-branding method produces many price disparities.

Therefore, it is vital for culinary entrepreneurs or merchants who are members of the food e-commerce platform to reduce their dependence on the platform, start designing more flexible pricing strategies, and begin to take advantage of their social media platforms.

Based on these opportunities, Segmenting, Positioning, and Targeting analysis is carried out for the basis of the marketing strategy to be made and as one of the considerations for determining the subscription price range.
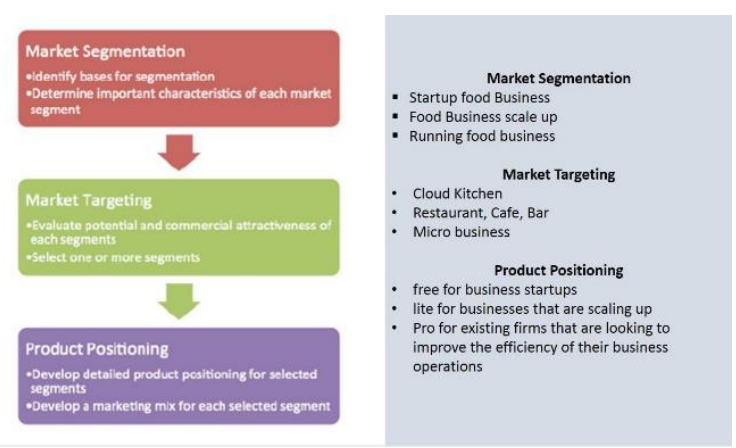

Figure 3. STP rumahmakan.online

The rumahmakan.online has a segmentation for novice food businesses, food businesses starting a scale-up, and food businesses already running and having a physical location. In addition, online restaurant targets cloud kitchen businesses, restaurants, cafes, bars, restaurants, and MSMEs as the target market.

To achieve the predetermined target, online restaurant positions subscription products from "Free" for novice businessmen, "Lite" for business people who plan to develop their business such as MSMEs or scale-ups, and "Pro" for 
companies that are already running and are trying to do business. Business efficiency and development marketing through digital marketing. In carrying out the marketing activities of rumahmakan.online, analyze the 4P marketing mix (Product, Place, Price, Promotion) as follows:

a. Product

Applications Website digital menu WhatsApp ordering system

b. Place

The website is located at https://rumahmakan.online, and the office is in Bandung.

c. Price

Rumahmakan.online mempunyai range harga berlanganan perbulan dari Gratis, Rp.35.000, Rp.100.000,-

d. Promotion

The promotion strategy that has been planned is:

- Word Of Mouth

- Social media and google ads

- Co-Branding

Carrying out operational activities requires some costs and some inventory. The following details the initial inventory requirements as follows::

Table 1. Initial investment requirement

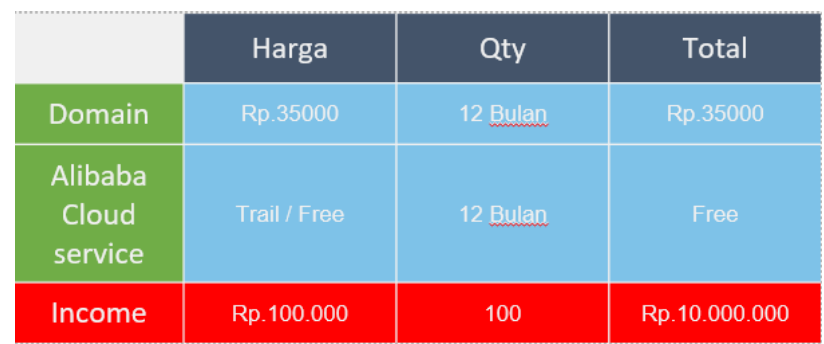

This is the start-up cost of a rumahmakan. Along with the expansion of the rumahmakan.online firm, you must design a development plan, or scale-up, and below is a predicted scale-up budget:
Table 2. Initial ScaleUP Investment fee

\begin{tabular}{|l|c|c|r|}
\hline \multicolumn{4}{|c|}{ Monthly Expenses } \\
\hline \multicolumn{1}{|c|}{ Direksi } & Pax & Price & \multicolumn{1}{|c|}{ Total } \\
\hline CEO & 1 & 5.000 .000 & 5.000 .000 \\
\hline CTO & 1 & 5.000 .000 & 5.000 .000 \\
\hline & & & \\
\hline Employee/ Manning & & & \\
\hline FullstuckDeveloper & 1 & 3.500 .000 & 3.500 .000 \\
\hline Marketing & 1 & 3.500 .000 & 3.500 .000 \\
\hline Admin & 1 & 3.500 .000 & 3.500 .000 \\
\hline & & & \\
\hline & & & \\
\hline Employee Allowance & & & \\
\hline Pulsa & 1 & 150.000 & \\
\hline Uang Makan & 5 & 15.000 & \\
\hline & & & 75.000 \\
\hline Office Equipment & & & \\
\hline PC/ Laptop & & & \\
\hline Stationary & & 300.000 & \\
\hline & & & 300.000 \\
\hline Digital Marketing & 1 & 2.000 .000 & \\
\hline & & & 2.000 .000 \\
\hline CDN & 1 & 300.000 & \\
\hline Server & 1 & 720.000 & 300.000 \\
\hline Ruangan/ Office & 1 & 3.000 .000 & 3.000 .000 \\
\hline & & & 27.045 .000 \\
\hline & & Total & \\
\hline & & & \\
\hline
\end{tabular}

With the projected business development expenditure as above, rumahmakan.online plan revenue streams as follows:

Tabel 3. Revenue Stream

\begin{tabular}{|l|c|c|c|}
\hline \multicolumn{1}{|c|}{ Income } \\
\hline \multicolumn{1}{|c|}{ Income } & Pax & Unit & \multicolumn{1}{c|}{ Jumlah } \\
\hline Adssense & & & \\
\hline Subscribe & 280 & 100.000 & 28.000 .000 \\
\hline & & & \\
\hline Total Kotor & & & \\
\hline ppn 10\% & & & 28.000 .000 \\
\hline Nett Income & 280 & 10.000 & 280.000 \\
\hline & & & $\mathbf{2 7 . 7 2 0 . 0 0 0}$ \\
\hline NOP & & & \\
\hline
\end{tabular}

The table below shows the minimal revenue for the rumahmakan.online to function smoothly and develop. With the expected income and costs, rumahmakan.online has a break event point forecast as shown below.: 
Tabel 4. Break even point

\begin{tabular}{|l|c|c|cr|}
\hline \multicolumn{1}{|c|}{ Account } & Pax & \multicolumn{1}{c|}{ Amount } & \multicolumn{2}{|c|}{ Total } \\
\hline $\begin{array}{l}\text { Operational } \\
\text { Cost }\end{array}$ & 12 & IDR 27.045.000 & IDR & 324.540 .000 \\
\hline $\begin{array}{l}\text { Minimum } \\
\text { Income } \\
\text { projection }\end{array}$ & 12 & IDR 27.720.000 & IDR & 332.640 .000 \\
\hline & & & IDR & 8.100 .000 \\
\hline
\end{tabular}

With a minimum income covering operational costs, it is estimated that rumahmakan.online can still benefit. This profit income is the minimum standard for the marketing team. It is hoped that the rumahmakan.online marketing team reaches the target two times the stated mark.

\section{Conclusion}

Rumahmakan.online is a digital menu web application platform with a WhatsApp ordering system feature, where the core of its business identity is a social entrepreneur so that business development and product sales must impact social life. The primary purpose of presenting this platform is to help people who are starting or developing the food business by utilizing digital media, as well as one of the tools for restaurants, cafes, bars, and businesses to carry out the CHSE program by minimizing contacts that occur in the services provided.

Planning to strategy formulation has been carefully planned in the business plan listed in this journal. Rumahmakan.online seeks to make its business plan mature with the current conditions. Including Marketing, finance, and technology projects, each strategy has been adjusted according to the previously analyzed SWOT.

\section{References}

Buchari Alma. (2016). Manajemen Pemasaran dan Pemasaran Jasa. Bandung. Alfabeta.

Carissa, \& Onna, A. (2014). PENERAPAN
CUSTOMER RELATIONSHIP MANAGEMENT (CRM) SEBAGAI UPAYA UNTUK MENINGKATKAN LOYALITAS PELANGGAN (Studi Kasus pada Bandung Sport Distro Malang). Jurnal Administrasi Bisnis, 15(1).

http://administrasibisnis.studentjournal .ub.ac.id/index.php/jab/article/view/60 2

Chaffey, D. dan Ellis-Chadwick, F. 2016. Digital Marketing Strategy, Implementation, and Practice. New Jersey : Pearson Publishing.

Chang, W.-L. (2009). Roadmap of Cobranding Positions and Strategies. Undefined.

C Ningsih and YJ Choi (2018). An Effect of Internet Penetration on Income Inequality in Southeast Asian Countries. Calgary: International Telecommunications Society (ITS).

Djaslim Saladin. (2016). Manajemen Pemasaran. Bandung: Agung Ilmu.

Durianto, D., Sugiarto, \& Budiman, L. J. (2004). Brand Equity Ten Strategi Memimpin Pasar - Google Books. Gramedia Pustaka Utama. https://books.google.co.id/books?hl=e $\mathrm{n} \& \mathrm{lr}=\& \mathrm{id}=\mathrm{S} 4 \mathrm{MDGeY} 68 \mathrm{EYC} \& \mathrm{i}=\mathrm{fnd}$ $\& p g=P P 9 \& d q=$ Penentuan + posisi + ini + dilakukan+untuk+mengukur+produk+ atau+brand+kita+berada+di+area+ma na\&ots=fWfWt2ISEg\&sig=JfOIrDoO LmxVpOGU5P-

DXhGSHJg\&redir_esc $=\mathrm{y} \# \mathrm{v}=$ onepage $\& \mathrm{q}=$ Penentuan posisi in

Erick Berkowits, A.M, Morissan. 2010. Periklanan komunikasi pemasaran terpadu, Jakarta: Penerbit Kencana.

Fandy Tjiptono dan Gregorius Chandra. (2016). Service, Quality \& satisfaction. Yogyakarta. Andi

Ferrel, O. ., \& Hartline, M. D. (2011). 
Marketing Strategy. Cengage Learning

Guo, X., \& Zheng, X. (2017). Examination of Restaurants Online Pricing Strategies: A Game Analytical Approach. Journal of Hospitality Marketing and Management, 26(6), 659-673.

https://doi.org/10.1080/19368623.201

7.1272085

Hanafiah, H., \& Prasetya, R. (2021). IMPLEMENTASI PEMASARAN DIGITAL KEDAI KOPI OM BEWOK DALAM MEM-BRANDING KOPI LOKAL ROBUSTA ASLI BANTEN. In Business, Entrepreneuship and Finance (Vol. 1, Issue 1).

Kotler, Philip and Gary Amstrong. (2016). Prinsip-prinsip Pemasaran. Edii13.Jilid 1. Jakarta:Erlangga.

Kotler, Philip (2006). Manajemen Pemasaran, Edisi Pertama. Indonesia: PT. Indeks Kelompok Gramedia.

Kotler, Philip and Kevin Lane Keller, (2016). Marketing Managemen, 15th Edition, Pearson Education,Inc.

Kotler, P., Kartajaya, H., \& Setiawan, I. (2017). Marketing 4.0. John Wiley \& Sons, Inc.

Peter Paul, C. O. J. (2010). Consumer Behavior and Marketing Strategy,. https://www.amazon.com/Consumer-

Behavior-Marketing-Strategy-

Mcgraw-Hill/dp/0071111778

Pranawukir, I., \& Sukma, A. H. (2021). Strategi Corporate Social Responsibility Dompet Dhuafa dalam Membangun Brand Differentiation Lembaga. Jurnal Inovasi Ilmu Sosial Dan Politik (JISoP), 3(1), 22. https://doi.org/10.33474/jisop.v3i1.90 00

Rangkuti, F. (2010). Strategi Promosi yang Kreatif dan Analisis Kasus Integrated Marketing Communication. Gramedia Pustaka Utama. https://openlibrary.telkomuniversity.ac .id/pustaka/10162/strategi-promosiyang-kreatif-dan-analisis-kasusintegrated-marketingcommunication.html

Rosanti, Y., \& Darma Tuah Putra, M. (n.d.). Prosiding Konferensi Nasional Ekonomi Manajemen dan Akuntansi (KNEMA) Journal Homepage Tantangan dan Strategi Customer Relationship Marketing dengan Prinsip Cleanliness, Health, and Safety (CHS) dalam Upaya Pemulihan Ekonomi di Kawasan Wisata Samosir. Sarinastiti, E. N., \& Vardhani, N. K. (2019). CO-BRANDING ONLINE FOOD DELIVERY: PERUBAHAN MODEL BISNIS WISATA KULINER LOKAL KHAS YOGYAKARTA. AdBispreneur, 3(3), 177. https://doi.org/10.24198/adbispreneur. v3i3.19157

Suprihatin, W. (2020). Analisis Perilaku Konsumen Wisatawan Era Pandemi Covid-19 ( Studi Kasus Pariwisata di Nusa Tenggara Barat ). Jurnal Bestari, 19, 56-66. https://jurnalbestari.ntbprov.go.id/inde x.php/bestari1/article/view/9/7

Syabania, R., \& Rosmawarni, N. (2021). PERANCANGAN APLIKASI CUSTOMER RELATIONSHIP MANAGEMENT (CRM) PADA PENJUALAN BARANG PREORDER BERBASIS WEBSITE. In Jurnal Rekayasa Informasi (Vol. 10, Issue 1).

Victor, V., Thoppan, J. J., Fekete-Farkas, M., \& Grabara, J. (2019). Pricing strategies in the era of digitalization and the perceived shift in consumer behavior of youth in Poland MMS 2018-3rd EAI International Conference on Management of Manufacturing Systems View project E-Commerce View project Pricing strategies in th. 
Journal of International Studies, 12(3), 74-91. https://doi.org/10.14254/20718330.2019/12-3/7 